\title{
Exercise-Induced Synaptogenesis in the Hippocampus Is Dependent on UCP2-Regulated Mitochondrial Adaptation
}

\author{
Marcelo 0. Dietrich, ${ }^{1,2,3,4}$ Zane B. Andrews, ${ }^{1,2,3,5}$ and Tamas L. Horvath ${ }^{1,2,3}$ \\ ${ }^{1}$ Section of Comparative Medicine and Departments of ${ }^{2}$ Obstetrics, Gynecology, and Reproductive Sciences and ${ }^{3}$ Neurobiology, Yale University School of \\ Medicine, New Haven, Connecticut 06520, 4Programa de Pós-graduação em Bioquímica de Bioquímica, Universidade Federal do Rio Grande do Sul, 90035 - \\ 003 Porto Alegre, RS, Brazil, and ${ }^{5}$ Department of Physiology, Monash University, Clayton, Victoria 3183 Australia
}

\begin{abstract}
Mitochondria are essential organelles in neurons providing appropriate energetic needs to maintain resting and action potentials as well as to modulate synaptic plasticity. Although neuronal events underlie various behavioral events, the behavior itself, such as voluntary exercise, feeds back to affect neuronal morphology and function as well as glial morphology and function. The hippocampal formation is a main site of synaptic plasticity induced by voluntary exercise. Here we show that voluntary exercise induces uncoupling protein 2 (UCP2) mRNA expression and mitochondrial oxygen consumption in coupled as well as uncoupled respiratory states in the hippocampus. These changes in mitochondrial metabolism coincided with an increase in mitochondrial number and dendritic spine synapses in granule cells of the dentate gyrus and the stratum radiatum of the CA1 region and were dependent on UCP2 expression, because in UCP2 knock-out mice such changes were not observed. Together, these observations reveal that a mitochondrial mechanism related to UCP2 function is essential for appropriate bioenergetic adaptation of neurons to increased neuronal activity and synaptic plasticity in response to exercise.
\end{abstract}

Key words: physical activity; mitochondria respiration; uncoupling activity; synaptic plasticity; exercise; dendritic spine

\section{Introduction}

Exercise is a behavioral intervention widely known to promote brain plasticity (Cotman and Berchtold, 2002). Regular exercise in rodents promotes hippocampal plasticity, increasing neurogenesis (van Praag et al., 1999a), long-term potentiation (van Praag et al., 1999b), and angiogenesis (Lopez-Lopez et al., 2004). These effects are coupled to mechanisms that increase energy demand in this brain area. Indeed, exercise enhances glucose uptake (Lopez-Lopez et al., 2004). These mechanisms must be coupled to oxidative energy transformation, dependent on mitochondrial respiration and the supply of energy substrates.

Uncoupling proteins (UCPs) are involved in mitochondrial processes and were first described as regulators of heat production in peripheral brown adipose tissue. One of these mitochondrial proteins, UCP2, is found in the CNS and has been implicated in various neuronal mechanisms (Andrews et al., 2005a). We and others have shown that UCP2 is involved in neuroprotection in mice models of Parkinson's disease (Andrews et al., 2005b; Conti et al., 2005), epilepsy (Diano et al., 2003), and stroke (Mattiasson et al., 2003) as well as in normal functioning of the

Received June 16, 2008; revised Aug. 24, 2008; accepted Sept. 11, 2008.

This work was supported by National Institutes of Health Grants DK 074386, DK 060711, DK 080000, and AG 022880 (T.L.H.). M.O.D. was supported by Conselho Nacional de Desenvolvimento Científico e Tecnológico, and Z.B.A. was the recipient of a New Zealand Foundation for Research Science and Technology Fellowship. We are indebted to Marya Shanabrough and Erzsebet Borok for their superb technical assistance and Dr. Brad Lowell for providing breeding pairs of UCP2 knock-out mice.

Correspondence should be addressed to Tamas L. Horvath, Section of Comparative Medicine, Yale University School of Medicine, 375 Congress Avenue, LSOG 117, New Haven, CT 06520. E-mail: tamas.horvath@yale.edu.

D0I:10.1523/JNEUROSCI.2744-08.2008

Copyright $\odot 2008$ Society for Neuroscience ～0270-6474/08/2810766-06\$15.00/0 nigrostriatal dopamine system (Andrews et al., 2006) and the arcuate nucleus melanocortin system (Coppola et al., 2007; Andrews et al., 2008). Induction of UCP2 expression in the brain by cellular stress increases the overall production of ATP, perhaps as a result of stimulation of mitochondrial proliferation, while decreasing superoxide production and associated damage (Bechmann et al., 2002; Diano et al., 2003, Andrews et al., 2005b, 2008).

Despite the important role that the mitochondria play in neuronal functions, there is a paucity of information regarding the potential direct role of this organelle in neuronal function and plasticity in the adult brain. An elegant study by Li et al. (2004) provided in vitro evidence that there is a dynamic mitochondrial response to neuronal activation and that this process is associated with synaptic plasticity, especially synaptogenesis and spine formation. The objective of our present study was to reveal whether there may be an in vivo correlate of such a mitochondrial process and, if so, whether this mechanism may be regulated by UCP2. We studied exercise-induced changes in the hippocampus in wild-type (UCP2wt) and UCP2 knock-out (UCP2ko) animals.

\section{Materials and Methods}

Animals. Adult (3-4 months old) male and female mice were used in this study. UCP2ko mice were generated as described previously (Zhang et al., 2001) and were kindly provided by Dr. Bradford Lowell (Beth Israel Deaconess Medical Center and Harvard Medical School, Boston, MA). Mice were maintained in a $12 \mathrm{~h}$ light/dark cycle with water and food provided ad libitum, housed in rat cages (to accommodate the running wheel; $n=4$ per cage) equipped with a freely running wheel for 4 weeks. Sedentary (sed) controls were also maintained in rat cages but without the running wheel. Ten animals were analyzed for each readout. All procedures were approved by the Institutional Animal Care and Use 
Committee of Yale University. Wheel running activity was monitored at random times during the dark and light cycle.

Semiquantitative reverse transcription-PCR. Frozen hippocampus tissue was thawed into Trizol. RNA and cDNA were prepared as described previously (Diano et al., 2003). Reverse transcription-PCR was performed as described previously (Horvath et al., 2003) using primers for UCP2 (forward, 5'-CTACAAGACCATTGCACGAGAGG-3'; reverse, 5'-AGCTGCTCATAGGTGACAAACAT-3'), UCP4 (forward, 5'-GTGAAGGTCCAGATGCAAATG-3'; reverse, 5' -CATTCTCAGCCACGAGGG-3'), and UCP5 (forward, 5'-TGGGGTAGTGTCAGGAGT-

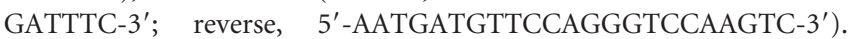
Specificity of amplification was confirmed by sequencing bands from test reactions. Amplification threshold values were measured, and endpoint reaction samples were run on $1 \%$ agarose gels in ethidium bromide to confirm the size and intensity of bands detected. UCP1 and UCP $3 \mathrm{mR}-$ NAs were not assessed, because these transcripts have not been found in the brain (Andrews et al., 2005a).

Mitochondrial isolation and respiration measurements. The hippocampus was rapidly dissected and homogenized in the isolation buffer ( $215 \mathrm{~mm}$ mannitol, $75 \mathrm{~mm}$ sucrose, $0.1 \%$ fatty acid-free BSA, 20 mM HEPES, and $1 \mathrm{~mm}$ EGTA, pH adjusted to 7.2 with $\mathrm{KOH}$ ). The homogenate was spun at $1300 \times g$ for $3 \mathrm{~min}$, the supernatant was removed, and the pellet was resuspended with isolation buffer and spun again at $1300 \times g$ for $3 \mathrm{~min}$. The two sets of supernatants from each sample were topped off with isolation buffer and spun at $13,000 \times g$ for $10 \mathrm{~min}$. The supernatant was discarded, and the step was repeated. After this second spin at $13,000 \times g$, the supernatant was discarded, and the pellets were resuspended with isolation buffer without EGTA and spun at $10,000 \times g$ for $10 \mathrm{~min}$. The final synaptosomal pellet was resuspended with $50 \mu \mathrm{l}$ of isolation buffer without EGTA. Protein concentrations were determined with a BCA protein assay kit (Pierce). Mitochondrial respirations were assessed using a Clark-type oxygen electrode (Hansatech Instruments) at $37^{\circ} \mathrm{C}$ with pyruvate and malate ( 5 and $2.5 \mathrm{~mm}$ ) as oxidative substrates in respiration buffer $(215 \mathrm{~mm}$ mannitol, $75 \mathrm{~mm}$ sucrose, $0.1 \%$ fatty acid-free BSA, $20 \mathrm{~mm}$ HEPES, $2 \mathrm{~mm} \mathrm{MgCl}$, and $2.5 \mathrm{~mm} \mathrm{KH}_{2} \mathrm{PO}_{4}$, $\mathrm{pH}$ adjusted to 7.2 with $\mathrm{KOH}$ ). With the addition of oligomycin, uncoupled proton conductance was measured. Total respiration capacity was also measured after the addition of the photonophore carbonyl cyanide 4-(trifluoromethoxy) phenylhydrazone (FCCP). For analysis of ADPdependent, coupled respiration, ADP was added after the addition of oxidative substrates.

Electron microscopy. Vibratome sections (50 $\mu \mathrm{m}$ thick) were cut from blocks of tissue containing the hippocampus and washed in $0.1 \mathrm{M}$ phosphate buffer $(\mathrm{PB})$. Sections were osmicated (15 min in $1 \%$ osmium tetroxide in $\mathrm{PB}$ ) and dehydrated in increasing ethanol concentrations. During the dehydration, $1 \%$ uranyl acetate was added to the $70 \%$ ethanol to enhance ultrastructural membrane contrast. Dehydration was followed by flat embedding in Araldite. Ultrathin sections were cut on a Leica ultra microtome, collected on Formvar-coated single-slot grids, and analyzed with a Tecnai 12 Biotwin (FEI) electron microscope.

Quantitative synaptology and counting of mitochondria. The analysis of synapse number was performed in an unbiased manner (Pinto et al., 2004; Horvath and Gao, 2005; Diano et al., 2006) and is presented as number of synapses per cubic micrometer of tissue.

Mitochondrial number was determined using the optical dissector method on electron micrographs (Diano et al., 2003; Coppola et al., 2007). Sections to be sampled were randomly selected, and smaller grid areas $\left(100 \mu \mathrm{m}^{2}\right)$ were chosen from within each section in a similar systematic random manner. Within each area, an optical section was established between the surfaces of the tissue section, thus creating a threedimensional sampling area of known dimensions. All mitochondrial planes within this area were counted, provided that they did not cross three of the borders of the sampling boxes considered as exclusionary borders. The counts obtained from these sampling boxes were determined and represent the number of mitochondria per unit volume of the structure of interest.

Statistical analysis. An $F$ test analysis revealed a significant nonhomogeneity of variances between groups. The Kruskal-Wallis one-way non- a

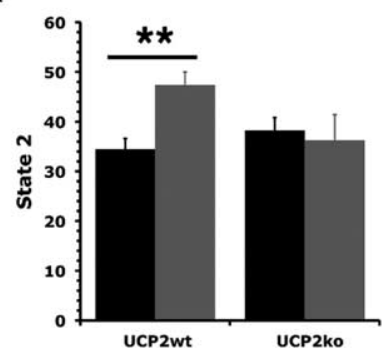

- sedentary

nexercise

b

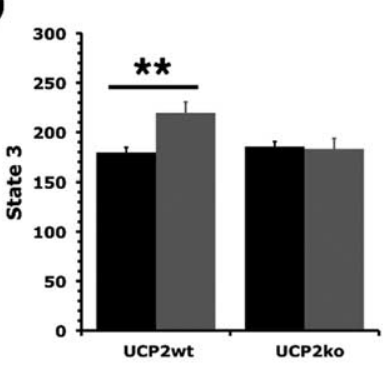

C

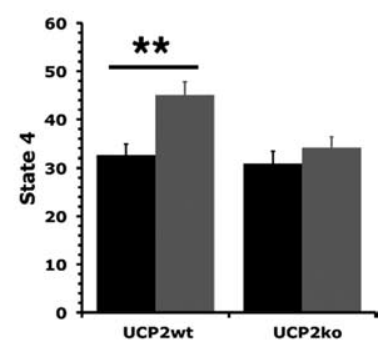

d
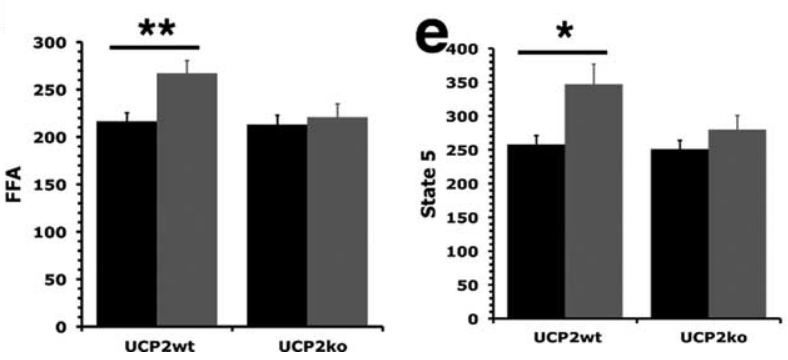

Figure 1. Mitochondrial respiration in sedentary ( $n=10$ of each genotype) and exercised ( $n=10$ of each genotype) UCP2wt and UCP2ko mice. $\boldsymbol{a}$, State 2 respiration after addition of palmitate/malate in the respiration buffer. $\boldsymbol{b}$, State 3 respiration induced by ADP. c, State 4, representing respiration after addition of oligomycin, an $\mathrm{H}^{+}$-transporting ATP synthase inhibitor. $\boldsymbol{d}$, FFA-induced mitochondrial respiration. $\boldsymbol{e}$, Total uncoupling activity after addition of $\mathrm{FCCP}$. In the histograms, the $y$-axis units are nanomoles of $0_{2}$ per minute per milligram of protein. ${ }^{*} p<0.05 ;{ }^{* *} p<0.01$. Error bars represent SEM.

parametric ANOVA was selected for multiple statistical comparisons. The Mann-Whitney $U$ test was used to determine significance of differences between groups. $p<0.05$ was considered statistically significant.

\section{Results}

\section{Exercise-induced hippocampal mitochondrial respiration is} dependent on UCP2

We first explored whether voluntary exercise in mice, which induces hippocampal cell activation (Czurkó et al., 1999), could promote mitochondrial adaptation. First we determined that exercise induces increased UCP2 gene expression in wild-type mouse hippocampus $(120 \pm 10 \%$ compared with sedentary values; $p<0.05)$. No changes were observed in UCP4 $(93 \pm 5 \%)$ or UCP5 $(91 \pm 12 \%)$ mRNA expressions, and no effect was detected on either UCP4 or UCP5 gene expression in UCP2ko animals (data not shown). When UCP2 expression was analyzed in a gene trap knock-out line in which LacZ is inserted in the UCP2 gene (Horvath et al., 2002), we observed the most dense $\beta$-galactosidase-labeled nuclei in the granule layer of the dentate gyrus (DG), whereas few labeled cells could also be found in the pyramidal layer of the CA3 and CA1 regions (data not shown).

Next we studied the effects of exercise on mitochondrial respiration of wild-type and UCP2 knock-out mice. Voluntary 

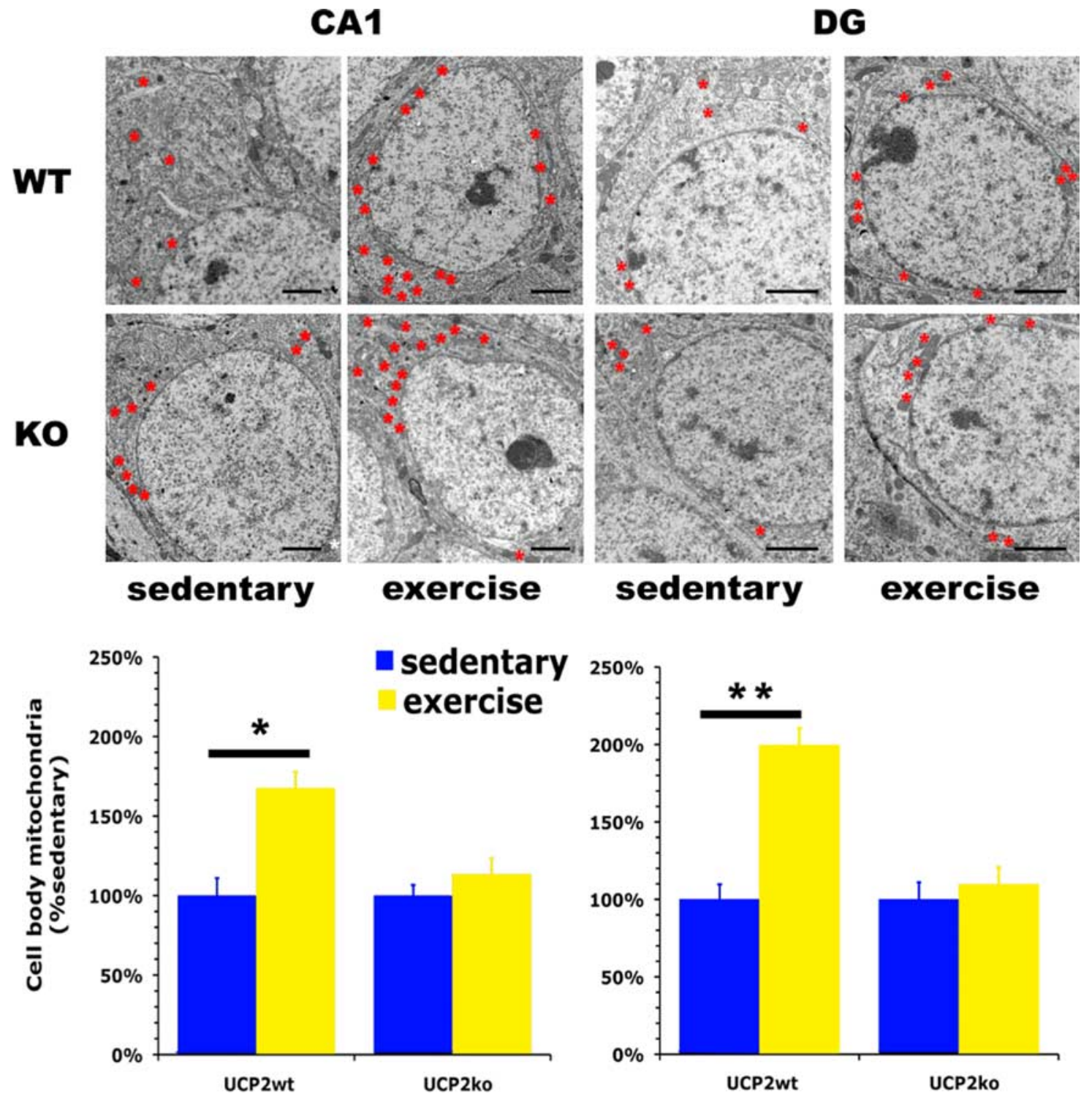

Figure 2. Mitochondrial number in the cell body of neurons from the dentate gyrus and CA1 of sedentary ( $n=10$ of each genotype) and exercised ( $n=10$ of each genotype) UCP2wt and UCP2ko mice. Top, Representative electron microscopic images of neuronal cell bodies with mitochondria marked in red. Bottom left, Histogram representing a quantitative analysis of mitochondrial number in cell bodies of CA1 pyramidal neurons. Bottom right, Histogram representing mitochondrial number in DG neurons. Scale bars, $1 \mu \mathrm{m} .{ }^{*} p<0.05 ;{ }^{* *} p<0.01$. Error bars represent SEM.

exercise, which was not significantly different $(p>0.05)$ between wild-type $(3487 \pm 246 \mathrm{~m} / \mathrm{d}$; mean \pm SEM) and UCP2 knock-out mice $(3195 \pm 176 \mathrm{~m} / \mathrm{d}$; mean $\pm \mathrm{SEM})$, induced elevations in oxygen consumption in all states of mitochondrial respiration in wild-type but not in knock-out mice (Fig. 1): state 2 [UCP2wt: sed, $34.46 \pm 2.13$; exercised (exe), $47.38 \pm 2.64$; UCP2ko: sed, $38.24 \pm 2.55$; exe, $36.25 \pm 5.13$ $\mathrm{nmol} \mathrm{O}_{2} \cdot \mathrm{min}^{-1} \cdot \mathrm{mg}^{-1}$ protein], state 3 (mitochondrial respiration coupled to ATP production; UCP2wt: sed, $179.31 \pm$ 5.52; exe, $219.32 \pm 11.03$; UCP2ko: sed, $185.18 \pm 5.25$; exe, $183.05 \pm 10.77 \mathrm{nmol} \mathrm{O}_{2} \cdot \mathrm{min}^{-1} \cdot \mathrm{mg}^{-1}$ protein), state 4 (base uncoupled respiration; UCP2wt: sed, $32.59 \pm 2.31$; exe, $45.02 \pm 2.77$; UCP2ko: sed, $30.95 \pm 2.40$; exe, $34.11 \pm 2.25$ $\mathrm{nmol} \mathrm{O}_{2} \cdot \mathrm{min}^{-1} \cdot \mathrm{mg}^{-1}$ protein), free-fat acid (FFA)-induced uncoupled respiration (UCP2wt: sed, $216.43 \pm 8.80$; exe, $264.14 \pm 13.31$; UCP2ko: sed, $213.15 \pm 9.71$; exe, $220.71 \pm$ $14.05 \mathrm{nmol} \mathrm{O}_{2} \cdot \mathrm{min}^{-1} \cdot \mathrm{mg}^{-1}$ protein), and FCCP-induced oxygen consumption (UCP2wt: sed, $257.41 \pm 13.46$; exe,
$346.78 \pm 30.15$; UCP2ko: sed, $250.91 \pm 13.06$; exe, $279.94 \pm$ $20.86 \mathrm{nmol} \mathrm{O}_{2} \cdot \min ^{-1} \cdot \mathrm{mg}^{-1}$ protein).

Exercise increases cell body mitochondrial number in hippocampal neurons dependent on UCP2

Because we determined that exercise increases mitochondrial respiration and was dependent on UCP2, we further explored whether exercise could alter mitochondria number. Compared with sedentary controls, 4 weeks of voluntary exercise increased the number of cell body mitochondria in neurons of the CA1 region by $67 \%$ (sedentary, $0.29 \pm 0.03$; exercise $0.49 \pm 0.05$ mitochondria/ $\mu \mathrm{m}^{2}$ cytoplasm area; $p<0.001$ ) and of the DG by $99 \%$ (sedentary, $0.29 \pm 0.03$; exercise, $0.57 \pm$ 0.06 mitochondrion $/ \mu \mathrm{m}^{2}$ cytoplasm area; $p<0.001$ ) in UCP2wt mice (Fig. 2). As seen with mitochondrial respiration, exercise did not increase the number of mitochondria in the hippocampal cell bodies of UCP2ko mice either in the CA1 region (sedentary, $0.39 \pm 0.03$; exercise, $0.45 \pm 0.04$ mito- 

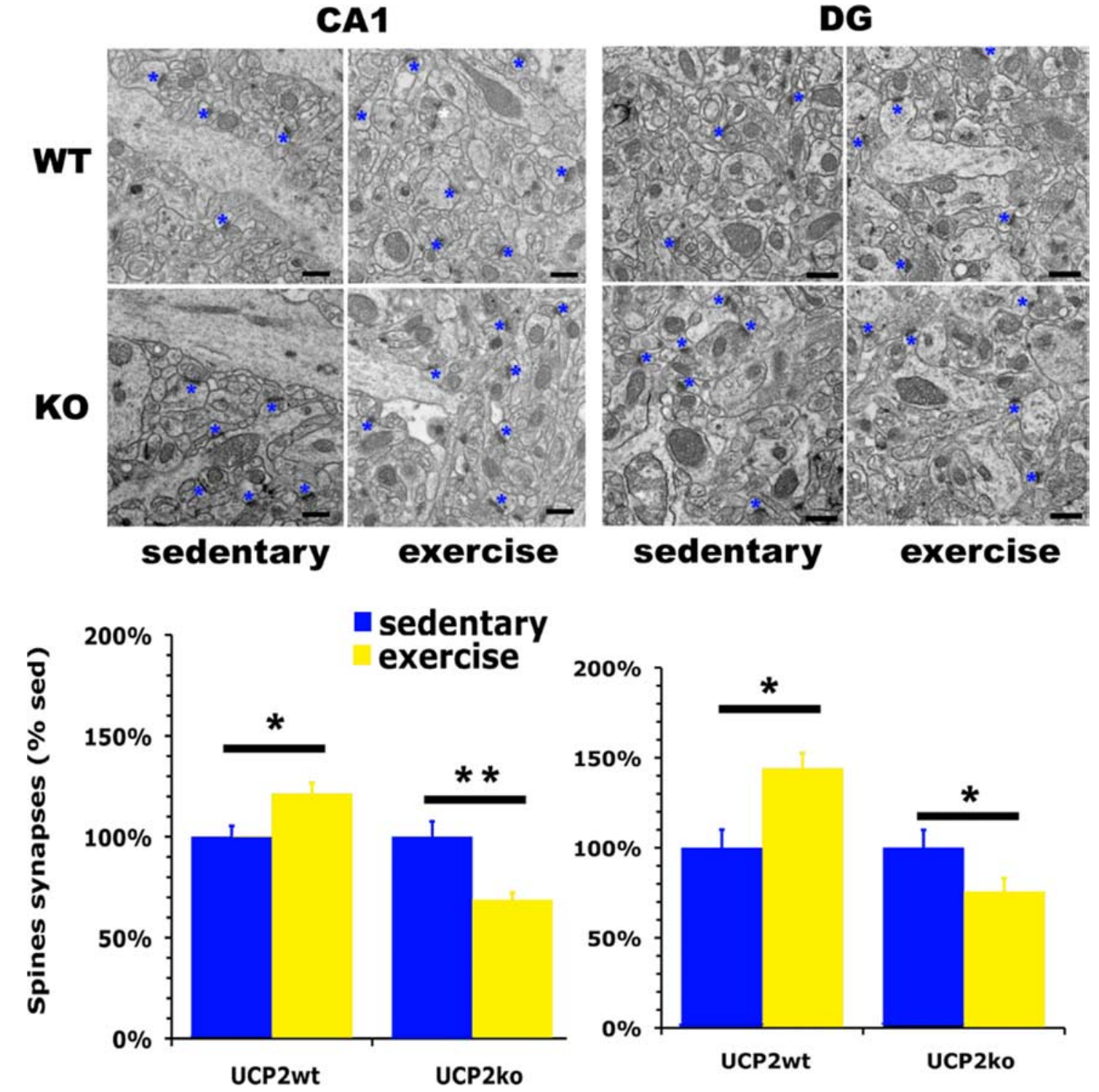

Figure 3. Spine synapse counts of neurons from the dentate gyrus and CA1 of sedentary ( $n=10$ of each genotype) and exercised ( $n=10$ of each genotype) UCP2wt and UCP2ko mice. Top, Representative electron microscopic images of spine synapses marked in blue. Bottom left, Histogram representing a quantitative analysis of spine synapse number in CA1 pyramidal neurons. Bottom right, Histogram representing spine synapse number in DG neurons. Scale bars, $1 \mu \mathrm{m} .{ }^{*} p<0.05 ;{ }^{* *} p<0.01$. Error bars represent SEM.

chondria/ $\mu \mathrm{m}^{2}$ cytoplasm area; $\left.p>0.05\right)$ or in the DG (sedentary, $0.40 \pm 0.04$; exercise, $0.44 \pm 0.05$ mitochondria $/ \mu \mathrm{m}^{2}$ cytoplasm area; $p>0.05$ ) (Fig. 2). Interestingly, in sedentary animals, the number of mitochondria in these neuronal populations was higher in UCP2ko mice than in UCP2wt mice (CA1: $135.24 \pm 6.64 \%, p<0.05$; DG: $139.43 \pm 10.98, p<$ $0.05)$. Note that the respiration measurements were analyzed from synaptosomal preparations, which contain high level of mitochondria from axon terminals. We suggest that similar to our recent findings in specific hypothalamic neuronal populations (Andrews et al., 2008), UCP2-mediated increase in mitochondria number is present in both the perikarya and axon terminals.

Exercise-induced hippocampal synaptogenesis is coupled to UCP2 expression

Because exercise has been proposed to induce synaptic plasticity (Cotman and Berchtold, 2002), we also assessed the number of spine synapses on dendritic spines of granule cells in the DG and pyramidal cells of the stratum radiatum of the CA1 region in UCP2wt and UCP2ko mice (Fig. 3). Exercise increased the number of synapses in UCP2wt mice in both the CA1 [121.25 \pm $5.44 \%$ (sed, $1.66 \pm 0.09$; exe, $2.10 \pm 0.11$ spine synapses $/ \mu \mathrm{m}^{3}$ ); $p<0.05]$ and DG [144.08 $\pm 8.53 \%$ (sed, $1.10 \pm 0.11$; exe, $1.59 \pm$ 0.14 spine synapses $\left.\left./ \mu \mathrm{m}^{3}\right) ; p<0.01\right]$. UCP2ko mice, after exercise, presented a paradoxical response with a decreased number of synapses in the CA1 [68.70 $\pm 3.63 \%$ (sed, $2.04 \pm 0.15$; exe, $1.40 \pm 0.05$ spine synapses $\left.\left./ \mu \mathrm{m}^{3}\right) ; p<0.001\right]$ and DG $[75.63 \pm$ $7.51 \%$ (sed, $1.73 \pm 0.17$; exe, $1.31 \pm 0.10$ spine synapses $/ \mu \mathrm{m}^{3}$ ); $p<0.05]$. Similar to the results on mitochondria number, sedentary UCP2ko showed a higher number of synapses than sedentary UCP2wt mice (CA1: $122.87 \pm 7.59 \%, p<0.05$; DG: $156.58 \pm 9.99 \%, p<0.001)$.

\section{Discussion}

This study revealed that voluntary exercise in mice increases mitochondrial respiration, mitochondria number, and spine synapse density in the dentate gyrus and the CA1 region of the 
hippocampus, all of which are dependent on UCP2. In addition, UCP2ko mice manifested decrease in the number of synapses in both the CA1 and DG neurons in response to voluntary exercise, emphasizing the critical role for this mitochondrial protein in bioenergetic adaptation of neurons to increased cellular activity.

In certain species, the brain is responsible for $\sim 10 \%$ of the total energy expenditure, whereas in humans this value rises to $20 \%$. The brain is a tissue with high metabolic rate; it has been shown that $\sim 90 \%$ of all of the brain's energy is used to maintain basal neuronal resting and action potentials (Attwell and Laughlin, 2001). Thus, slight increases in overall neuronal activity can generate a great increase in brain energy consumption. Physical exercise in rodents increases neuronal activity in the hippocampus (Czurkó et al., 1999). This occurs with a concomitant increase in the mechanisms of energy supply and energy usage by neurons and glial cells. Some authors have shown that exercise increases angiogenesis, an important mechanism by which tissue can be better supplied with nutrients and thus increase the metabolic capacity (Lopez-Lopez et al., 2004). Also, exercise-induced increases in mitochondrial activity and number have been described in muscle, an important adaptation to the high metabolic demand placed on this tissue during physical exercise (Irrcher et al., 2003). Our results showed similar mechanisms in hippocampal neurons with exercise inducing mitochondrial respiration and number, which in turn is likely to contribute to an overall increase in ATP production (Diano et al., 2003; Andrews et al., 2005a).

Our data reinforce the role of uncoupling proteins in promoting brain plasticity and their participation in physiological and pathological adaptations of the brain. Moreover, because exercise protects the brain against a myriad of injuries, and because of our finding that exercise-induced both mitochondrial and synaptic plasticity were dependent on UCP2 expression, these data can be taken together with previously published findings to strengthen the assertion that UCP2 is important in neuroprotection (Bechmann et al., 2002; Diano et al., 2003; Mattiasson et al., 2003; Andrews et al., 2005b). Indeed, these data highlight the role of UCPs as possible new targets of brain therapies with likely implications for many brain pathologies that are associated with energy deficits such as Parkinson's disease, schizophrenia, epilepsy, Alzheimer's disease, and many others.

Interestingly, we showed that in response to exercise, UCP2ko mice exhibited a decrease in the number of spine synapses on dendritic terminals of hippocampal neurons. This is consistent with the possibility that exercise-induced neuronal activation triggers increased free radical production, a process that is not counteracted by UCP2 in these transgenic animals (Andrews et al., 2005a,b, 2008). In absence of appropriate mitochondrial uncoupling, a physiological stimulus such as exercise that normally promotes positive brain plasticity can, in fact, result in a deleterious effect, perhaps because of increased production of free radicals. UCP2 has been shown to be a radical scavenger (Echtay et al., 2002; Produit-Zengaffinen et al., 2007; Giardina et al., 2008), which is one of the likely mechanisms via which UCP2 can exert a protective effect on cellular and synaptological adaptations to increased workload on hippocampal neuron triggered by increased voluntary exercise.

Together, our results reveal a new mechanism of exerciseinduced brain plasticity through a mitochondria-dependent pathway related to the expression of UCP2.

\section{References}

Andrews ZB, Horvath B, Barnstable CJ, Elsworth J, Yang L, Beal MF, Roth RH, Matthews RT, Horvath TL (2005a) Uncoupling protein-2 is critical for nigral dopamine cell survival in a mouse model of Parkinson's disease. J Neurosci 25:184-191.

Andrews ZB, Diano S, Horvath TL (2005b) Mitochondrial uncoupling proteins in the CNS: in support of function and survival. Nat Rev Neurosci 6:829-840.

Andrews ZB, Rivera A, Elsworth JD, Roth RH, Agnati L, Gago B, Abizaid A, Schwartz M, Fuxe K, Horvath TL (2006) Uncoupling protein-2 promotes nigrostriatal dopamine neuronal function. Eur $\mathrm{J}$ Neurosci 24:32-36.

Andrews ZB, Liu Z-W, Wallingford N, Erion DM, Borok E, Friedman JM, Tschöp MH, Shanabrough M, Cline G, Shulman GI, Coppola A, Gao X-B, Horvath TL, Diano S (2008) UCP2 mediates ghrelin's action on NPY/ AgRP neurons by lowering free radicals. Nature 454:846-851.

Attwell D, Laughlin SB (2001) An energy budget for signaling in the grey matter of the brain. J Cereb Blood Flow Metab 21:1133-1145.

Bechmann I, Diano S, Warden CH, Bartfai T, Nitsch R, Horvath TL (2002) Brain mitochondrial uncoupling protein 2 (UCP2): a protective stress signal in neuronal injury. Biochem Pharmacol 64:363-367.

Conti B, Sugama S, Lucero J, Winsky-Sommerer R, Wirz SA, Maher P, Andrews Z, Barr AM, Morale MC, Paneda C, Pemberton J, Gaidarova S, Behrens MM, Beal F, Sanna PP, Horvath T, Bartfai T (2005) UCP2 protects catecholaminergic neurons from acute MPTP toxicity. J Neurochem 93:493-501.

Coppola A, Liu ZW, Andrews ZB, Paradis E, Roy MC, Friedman JM, Ricquier D, Richard D, Horvath TL, Gao XB, Diano S (2007) A central thermogenic-like mechanism in feeding regulation: an interplay between arcuate nucleus T3 and UCP2. Cell Metab 5:21-33.

Cotman CW, Berchtold NC (2002) Exercise: a behavioral intervention to enhance brain health and plasticity. Trends Neurosci 25:295-301.

Czurkó A, Hirase H, Csicsvari J, Buzsáki G (1999) Sustained activation of hippocampal pyramidal cells by 'space clamping' in a running wheel. Eur J Neurosci 11:344-352.

Diano S, Matthews RT, Patrylo P, Yang L, Beal MF, Barnstable CJ, Horvath TL (2003) Uncoupling protein 2 prevents neuronal death including that occurring during seizures: a mechanism for preconditioning. Endocrinology 144:5014-5021.

Diano S, Farr SA, Benoit SC, McNay EC, da Silva I, Horvath B, Gaskin FS, Nonaka N, Jaeger LB, Banks WA, Morley JE, Pinto S, Sherwin RS, Xu L, Yamada KA, Sleeman MW, Tschöp MH, Horvath TL (2006) Ghrelin controls hippocampal spine synapse density and memory performance. Nat Neurosci 9:381-388.

Echtay KS, Roussel D, St-Pierre J, Jekabsons MB, Cadenas S, Stuart JA, Harper JA, Roebuck SJ, Morrison A, Pickering S, Clapham JC, Brand MD (2002) Superoxide activates mitochondrial uncoupling proteins. Nature 415:96-99.

Giardina TM, Steer JH, Lo SZ, Joyce DA (2008) Uncoupling protein-2 accumulates rapidly in the inner mitochondrial membrane during mitochondrial reactive oxygen stress in macrophages. Biochim Biophys Acta 1777:118-129.

Horvath B, Spies C, Horvath G, Kox WJ, Miyamoto S, Barry S, Warden CH, Bechmann I, Diano S, Heemskerk J, Horvath TL (2002) Uncoupling protein 2 (UCP2) lowers alcohol sensitivity and pain threshold. Biochem Pharm 64:369-374.

Horvath TL, Gao XB (2005) Input organization and plasticity of hypocretin neurons: possible clues to obesity's association with insomnia. Cell Metab 1:279-286.

Horvath TL, Diano S, Miyamoto S, Barry S, Gatti S, Alberati D, Livak F, Lombardi A, Moreno M, Goglia F, Mor G, Hamilton J, Kachinskas D, Horwitz B, Warden CH (2003) Uncoupling proteins-2 and 3 influence obesity and inflammation in transgenic mice. Int J Obes Relat Metab Disord 27:433-442.

Irrcher I, Adhihetty PJ, Joseph AM, Ljubicic V, Hood DA (2003) Regulation of mitochondrial biogenesis in muscle by endurance exercise. Sports Med 33:783-793.

Li Z, Okamoto K, Hayashi Y, Sheng M (2004) The importance of dendritic mitochondria in the morphogenesis and plasticity of spines and synapses. Cell 119:873-887.

Lopez-Lopez C, LeRoith D, Torres-Aleman I (2004) Insulin-like growth 
factor I is required for vessel remodeling in the adult brain. Proc Natl Acad Sci U S A 101:9833-9838.

Mattiasson G, Shamloo M, Gido G, Mathi K, Tomasevic G, Yi S, Warden $\mathrm{CH}$, Castilho RF, Melcher T, Gonzalez-Zulueta M, Nikolich K, Wieloch T (2003) Uncoupling protein-2 prevents neuronal death and diminishes brain dysfunction after stroke and brain trauma. Nat Med 9:1062-1068.

Pinto S, Roseberry AG, Liu H, Diano S, Shanabrough M, Cai X, Friedman JM, Horvath TL (2004) Rapid rewiring of arcuate nucleus feeding circuits by leptin. Science 304:110-115.

Produit-Zengaffinen N, Davis-Lameloise N, Perreten H, Bécard D, Gjinovci A, Keller PA, Wollheim CB, Herrera P, Muzzin P, AssimacopoulosJeannet F (2007) Increasing uncoupling protein-2 in pancreatic beta cells does not alter glucose-induced insulin secretion but decreases production of reactive oxygen species. Diabetologia 50:84-93.

van Praag H, Kempermann G, Gage FH (1999a) Running increases cell proliferation and neurogenesis in the adult mouse dentate gyrus. Nat Neurosci 2:266-270.

van Praag H, Christie BR, Sejnowski TJ, Gage FH (1999b) Running enhances neurogenesis, learning, and long-term potentiation in mice. Proc Natl Acad Sci U S A 96:13427-13431.

Zhang CY, Baffy G, Perret P, Krauss S, Peroni O, Grujic D, Hagen T, VidalPuig AJ, Boss O, Kim YB, Zheng XX, Wheeler MB, Shulman GI, Chan CB, Lowell BB (2001) Uncoupling protein-2 negatively regulates insulin secretion and is a major link between obesity, beta cell dysfunction, and type 2 diabetes. Cell 105:745-755. 